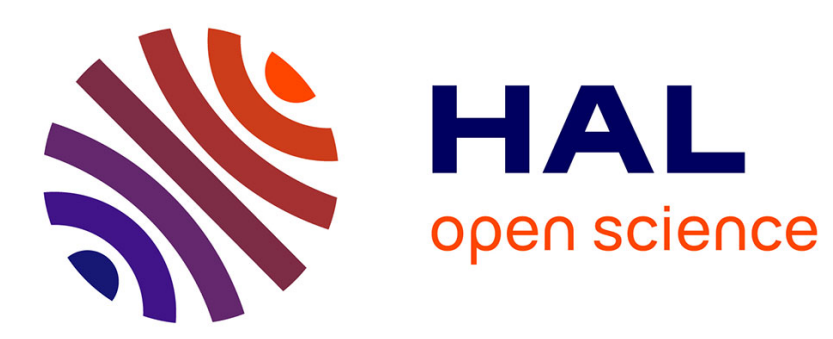

\title{
A mechano-biological model to predict the role of implant surfaces in the periprosthetic healing
}

Gaëtan Guérin, Dominique Ambard, Pascal Swider

\section{To cite this version:}

Gaëtan Guérin, Dominique Ambard, Pascal Swider. A mechano-biological model to predict the role of implant surfaces in the periprosthetic healing. 16th Congress of the european society of biomechanics, Jul 2008, Lucerne, Switzerland. pp.Cd-Rom. hal-00582902

\section{HAL Id: hal-00582902 https://hal.science/hal-00582902}

Submitted on 7 May 2013

HAL is a multi-disciplinary open access archive for the deposit and dissemination of scientific research documents, whether they are published or not. The documents may come from teaching and research institutions in France or abroad, or from public or private research centers.
L'archive ouverte pluridisciplinaire HAL, est destinée au dépôt et à la diffusion de documents scientifiques de niveau recherche, publiés ou non, émanant des établissements d'enseignement et de recherche français ou étrangers, des laboratoires publics ou privés. 


\title{
A MECHANO-BIOLOGICAL MODEL TO PREDICT THE ROLE OF IMPLANT SURFACES IN THE PERIPROSTHETIC HEALING
}

\author{
Gaëtan Guérin (1), Dominique Ambard (2), Pascal Swider (1) \\ 1. Biomechanics Laboratory, France; 2. LMGC UMR5508, France
}

\section{Introduction}

Conditions influencing bone growth in the early post-operative period include the surgical technique, mechanical [Prendergast, 1997] and biochemical factors [Bailón-Plaza, 2001]. Low performances of implant fixation were generally associated with a low mineralization or a strong heterogeneous distribution of bony structure in the new-formed surrounding tissue and the physicochemical properties of the implant surface might pay a significant role. We previously developed a mechanobiological model of healing coupling porous media mechanics to biomathematics [Ambard, 2006]. To go further, we hypothesized that such mathematical model could be completed to investigate the role of implant surface in cell proliferation, migration, and adhesion. The application concerned our stable canine implant [Vestermark, 2004].

\section{Methods}

The coupling of porous media mechanics and biomathematic allowed the diffusive-convectivereactive governing equations (1) to be derived; $L$, $C, D, \Omega$ respectively were the local variation, the convection, the diffusion, and the source terms.

$$
L \partial x / \partial t+C \operatorname{grad}(x)=D \Delta(x)+\Omega
$$

Output measures were the structural (or mineralized fraction) $\phi_{s}$, the fluid fraction $\phi_{f}$, the growth factor concentration $C_{g}$ (TGF- $\beta$ ) and the osteoblast concentration $C_{o}$. Structural porosity, fluid flow and growth factors conditionned the cellular behavior (proliferation, chemotactic \& haptotactic migrations, mineral fraction aposition). The cell adhesion influenced the motility through the cell diffusion coefficient $D_{o}$ dependant upon the substrate (bone or implant). The growth factor retention into the initial gap was modelled by a local diffusion coefficient. The source of growth factors involved the osteoblast concentration $C_{o}$, the growth factor concentration $C_{g}$ to take into account the autocrine and paracrine modes of TGF- $\beta$, and $\alpha_{g}$ dependant upon the osteoblast localization (bone or implant). The model of cell proliferation was similar (equ.3); $N_{o}$ being the proliferation threshold, $C_{0}$ the initial growth factor concentration.

$$
\begin{aligned}
& \Omega_{g}=\alpha_{g}\left(1-\phi_{S}\right)^{1.5} C_{o}^{0.5} C_{g} \\
& \Omega_{o}=\alpha_{o}\left(1-\phi_{S}\right)^{2} C_{o}\left[N_{o}-\left(1-\phi_{S}\right) C_{o}\right]\left(C_{g}-C_{0}\right)
\end{aligned}
$$

The PMMA implant [Vestermark, 2004] was the reference and we compared with two other surface treatments: acid-etched and coarse grit blasted acidetched with RGDS peptide. Material properties are given in Table 1 [Dee, 1999], [Rausch, 2007].

\begin{tabular}{cccc} 
& Acid & C-RGDS & PMMA \\
\hline$\alpha_{g}\left(\mathrm{e}^{-9} \mathrm{cell}^{-0.5} / \mathrm{s}\right)$ & 5.22 & 10.1 & 2.82 \\
$D_{o}\left(\mathrm{e}^{-7} \mathrm{~mm}^{2} / \mathrm{s}\right)$ & 1.75 & 1.45 & 1.75 \\
\hline \multicolumn{4}{c}{ Table 1: Material properties }
\end{tabular}

\section{Results}

The implant healing showed a polar symmetry and we plotted in Figure 1 the radial distribution of mineralized fraction from the implant surface toward the surrounding bone after 4 weeks. We observed the influence of implant surface properties since mineralized fraction increased from $62 \%$ for the PMMA implant to $85 \%$ for the C-RGD surface.

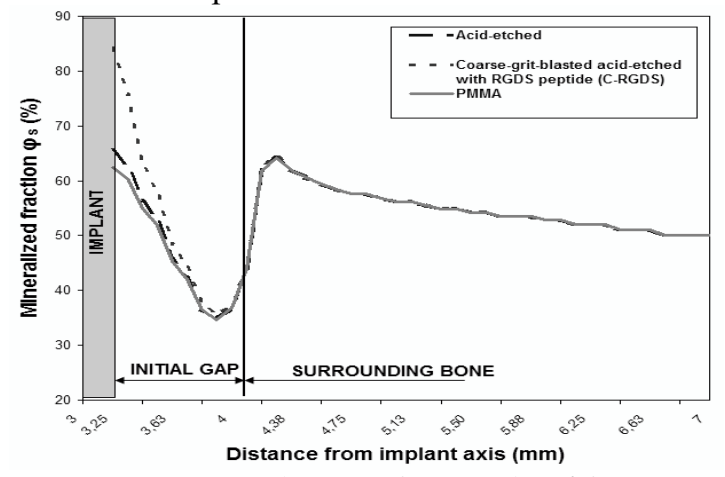

Figure 1: Distribution of mineralized fraction

\section{Discussion}

The TGF- $\beta$ synthesis coefficient $\alpha_{g}$ and cell diffusion coefficient $D_{o}$, were two main parameters that allowed the mechanobiological role of the implant surface to be predicted in time and space. The decrease of cell diffusion $\left(D_{o}\right)$ and the increase of growth factor synthesis $\left(\alpha_{g}\right)$ improved the bone formation. We also noticed that it was decreasing for the highest value of the litterature, probably because of a too rapid accumulation of cells in the vicinity of the implant and an early haptotactic migration towards the surrounding bone where the porosity gradient stayed important.

\section{References}

Ambard et al, E.JMech Sol/A, 25:927-937, 2006. Bailón-Plaza et al, J Theo Biol, 212:191-209, 2001. Dee KC et al, Biomaterials, 20:221-227, 1999. Prendergast et al, Clin Biomech 12:343-366, 1997. Rausch-Fan et al, Dent Mater, in press, 2007. Vestermark et al, J Orth. Res. 22(3):647-52, 2004. 